\title{
NEW APPROACH TO MODELLING OF SAND FILTER CLOGGING BY SEPTIC TANK EFFLUENT
}

\author{
Jakub Nieć', Marcin Spychała' ${ }^{1}$, Paweł Zawadzki ${ }^{1}$ \\ 1 Faculty of Land Reclamation and Environmental Engineering, University of Life Sciences in Poznan, Wojska \\ Polskiego 28,60-637 Poznań, Poland, e-mail:jniec@up.poznan.pl, marsp@up.poznan.pl, pzaw@up.poznan.pl
}

Received: 2016.02 .04

Accepted: 2016.03.04

Published: 2016.04.01

\begin{abstract}
The deep bed filtration model elaborated by Iwasaki has many applications, e.g. solids removal from wastewater. Its main parameter, filter coefficient, is directly related to removal efficiency and depends on filter depth and time of operation. In this paper the authors have proposed a new approach to modelling, describing dry organic mass from septic tank effluent and biomass distribution in a sand filter. In this approach the variable filter coefficient value was used as affected by depth and time of operation and the live biomass concentration distribution was approximated by a logistic function. Relatively stable biomass contents in deeper beds compartments were observed in empirical studies. The Iwasaki equations associated with the logistic function can predict volatile suspended solids deposition and biomass content in sand filters. The comparison between the model and empirical data for filtration lasting 10 and 20 days showed a relatively good agreement.
\end{abstract}

Keywords: clogging, filter coefficient, mathematical modelling, sand filter, solids deposition, suspended solids, biofilm processes.

\section{INTRODUCTION}

Solids blocking, deposition and sedimentation are one of main factors influencing flow conditions of two phase (solid/liquid) mixture in different environments, e.g. in porous material, micro-capillaries and macro-canals [Santos et al. 2008].

Filtration through soil and other granular materials is one of the most common and the oldest water [Valentukeviciene 2009] and wastewater treatment technologies, both for solids - particles [Cowan and Middlebrooks 1980] and dissolved substances [Renman et al. 2008] removal. An interesting use of sand filters is a disinfection of secondary clarifier effluent [Langenbach et al. 2010] or sand filters backwash residual use for the improvement of phosphorus removal in the wastewater treatment [Valentukeviciene and Ignatavicius 2014].

These solutions are popular especially in non-urbanized areas. These systems (sand filter drainage proceeded by septic tanks) are still used because of the simple construction and low costs of operation, especially for individual systems. Many studies [Duncan, 1994; Pell and Ljunggren 1996; Spychała 2003] showed that these systems can work with a high efficiency of organic and nitrogen compounds removal. The on-site (decentralized) systems have the potential for local water retention and water loading reduction [Shehabi et al. 2003]. The main disadvantage of this technology is a relatively high sensitivity to the clogging phenomenon [Błażejewski and MuratBłażejewska 1997].

It is known that one of main factors affecting clogging is solids loading and biomass growth. In some conditions, such as high solid and dissolved organic compounds loading and small media diameter (fine sand), solids accumulation in filtering media pores is a dominant clogging factor [Farajzadeh 2004].

Existing sophisticated models require parameters, which often have to be derived from experiments, so there is still a need for a simple formula 
for infiltration rate and clogging time assessment based on accumulated matter concentration.

In practice there is often the need to locate the soil infiltration system in a non-optimal environment for soil infiltration e.g. in fine sand. Unfortunately, small grain and pore diameters are prone to clogging [Nieć and Spychała 2014].

In this paper the authors have proposed a model, which describes dry organic mass and biomass concentration in a sand filter as a function of: inlet solids and dissolved organic compounds concentration, hydraulic load, time of application, filter coefficient and filter depth.

\section{MODELLING ASSUMPTIONS}

\section{Deposit of solids}

Solids removal from a solution can be conducted as a process of deposition in the pores or accumulation in front of the filtering layer surface (external cake build up). The deposition inside the pores is known as deep bed filtration [Farajzadeh 2004].

The deep filtration can be caused by various mechanisms [Elimelech and O'Melia 1990]:

- particle capture in porous media,

- gravity segregation,

- particle bridging,

- size exclusion (particle capture dependency, particle and pore size),

- electrical forces (double electrical layer, London-Van der Waals forces).

There are several mechanisms of transporting which are typical for large particles: interception, diffusion, hydrodynamic action, sedimentation, straining, ortho-kinetic flocculation [Keir et al. 2009] and removal mechanisms related to small particles [Jegatheesan and Vigneswaran 1997; Knowles et al. 2011], Brownian motion, electrostatic forces, surface area concentrations, bridging and coagulation.

Many authors [Loganet et al. 1995; Jegatheesan 1999; Zamani and Maini 2009] reported that spherical plastic particles of $1 \mu \mathrm{m}$ in diameter are too small for interception and sedimentation, and too large for diffusion and electrostatic forces to be significant for modelling. A similar range of values, $0.7-2 \mu \mathrm{m}$, was reported for influent and effluent of a horizontal subsurface flow in constructed wetlands in Spain by Puigagut et al. [2008].
Several authors [Zhao et al. 2009] found that clogging occurred in a relatively thin upper layer $(0-15 \mathrm{~cm})$ of filter and that clogging matter consists of inorganic and organic solids in a form of sludge and gels of high water content ( $60-70 \%$ of water).

Some important simplifications in modelling are made commonly, e.g. assumption of capillary tube flow with no transverse flow and no interactions between the particles and the wall. Usually the mixing of the suspension and constant concentration according to the cross section is also assumed [Fallah et al. 2012]. Other simplifications can be made in relation to the diffusion (e.g. due to its negligibility in the mass balance equation [Farajzadeh 2004; Herzig, et al. 1970].

Classical filtration theory elaborated by Iwasaki [Iwasaki 1937] taking into account a solute transport and mass balance equations [Logan 2001; Bradford et al. 2003; Foppen and Schijven 2006; Tufenkji 2007] is the most commonly used approach for evaluating migration, retention (sink term for solids deposition) and detachment (source term for solids deposition) [Ives 1975]:

$$
\begin{gathered}
\frac{\partial C}{\partial h}=-\lambda C_{0}, \\
\frac{\partial \sigma}{\partial t}=-q \cdot \frac{\partial C}{\partial h},
\end{gathered}
$$

where: $C$ - solids concentration in the filter $\left(\mathrm{VSS}, \mathrm{g} \cdot \mathrm{dm}^{-3}\right)$;

$C_{0}$ - initial solids concentration (VSS, $\left.\mathrm{g} \cdot \mathrm{dm}^{-3}\right)$;

$h$ - filter depth (m);

$\sigma$ - specific deposit of solids (VSS $\mathrm{g} \cdot \mathrm{sm}^{-3}$ );

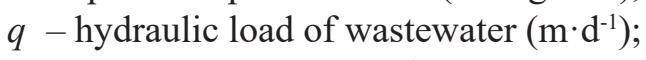

$\lambda$ - filter coefficient $\left(1 \cdot \mathrm{m}^{-1}\right)$;

$t$ - time (d).

After integration, equation (1) can be written in the form:

$$
C=C_{0} \cdot e^{-\lambda h},
$$

The filter coefficient $\lambda$ is believed to be a dominant parameter in particle filtration (transport and deposition processes) through the filtering (porous) medium.

There are many approaches to filter coefficient evaluation in deep bed filtration:

- macroscopic approach (macroscopic mass balance), where the filter coefficient corresponds to the flow conditions of a single collector or a bundle of single collectors (capillaries of very small diameter sometimes); 
- microscopic approach (microscopic trajectory analysis) - where the filter coefficient reflects the total collection efficiency as a summary result of Brownian diffusion, interception and settling [Fallah et al. 2012];

- probabilistic approach - where the filter coefficient is changeable along filter depth due to particle capture probability [Bedrikovetsky et al. 2011].

In the microscopic approach other forces and phenomena can be also taken into consideration such as impaction, straining and surface forces [Farajzadeh 2004].

The filter coefficient is directly related to removal efficiency and is variable with filter depth and time of operation. The filter coefficient is related mainly to a specific deposit of solids $\sigma$, noted by many investigators [Jabur et al. 2005]. There are many formulae representing variability of the filter coefficient. Most of them are derived from the model proposed by Ives [1960; 1969]. Some authors have suggested a division of the specific deposit into two parts: inconvertible and convertible ones [Jabur 1976; Öllös et al. 1987]. Jabur [2005] proposed to introduce a slow sand filter parameter, although the measurement of this parameter is sophisticated.

The filter coefficient is related to filter depth and time of operation and it has initial value (initial filter coefficient, $\lambda_{0}$ ) depends basically on sizes of solids and filter grains [Bai and Tien 1996].

The filter coefficient $\lambda$ has been associated with specific deposit of solids $\sigma$ in the form (eq. 4):

$$
\lambda=\lambda_{0} \cdot\left(\frac{\sigma_{\max }-\sigma}{\sigma_{\max }}\right)
$$

where: $\sigma_{\max }-$ constant (maximum specific deposit of solids) (VSS $\mathrm{g} \cdot \mathrm{dm}^{-3}$ ),

$\lambda_{0}-$ initial filter coefficient $\left(1 \cdot \mathrm{m}^{-1}\right)$.

Some examples of $\left(\lambda_{0}\right)$ values can be found in the literature, for instance - reported by Campos [2002], e.g. two values for algae accumulated in the filter with grains of $227 \mu \mathrm{m}$ diameter at two flow rate equal to $0.126 \mathrm{~m} \cdot \mathrm{h}^{-1}$ and flow rate equal to $0.292 \mathrm{~m} \cdot \mathrm{h}^{-1}: 1991 \cdot \mathrm{m}^{-1}$ and $1401 \cdot \mathrm{m}^{-1}$, respectively. The common physical interpretation of filter coefficient is based on its dependency on the effective surface of filter grains.

In conventional (Iwasaki) approach it is assumed that particles (of relatively small diameter) are removed from the fluid mainly in adsorp- tion-like processes and in relation to this, the determinative factor is a grain effective surface.

The approach presented in this study is based on the assumption that the filter coefficient is rather related to pore space than effective grain surface. Such an approach corresponds to a high concentration and relatively large solids particle diameter.

\section{Biomass concentration}

This function is commonly described in the literature [Tsoularis and Wallace 2002] and used for the estimation of the population of plants (Fresco 1973), animals [Aggrey 2002] and microorganisms [Zwietering et al. 1990], however, due to the impact of numerous factors there is a need for the empirical determination of some parameters, such as environmental capacity or growth coefficient.

The following logistic model (eq. 5) has been used by many researchers in unmodified and modified forms, e.g. for live organism and biomass concentration [Begon and Mortimer 1981]:

$$
\sigma_{b}(t)=\frac{K}{1+\left(\frac{K}{\sigma_{b_{o}}}-1\right) \cdot e^{-r \cdot t}},
$$

where: $\sigma_{b}(t)$ - biomass concentration after time $t$ in days $\left(\mathrm{g} \cdot \mathrm{dm}^{-3}\right)$;

$K$ - environmental capacity - maximum biomass concentration in particular environmental conditions $\left(\mathrm{g} \cdot \mathrm{dm}^{-3}\right)$;

$\sigma_{b 0}-$ initial biomass concentration (VSS $\left.\mathrm{g} \cdot \mathrm{dm}^{-3}\right)$;

$r$ - growth coefficient $\left(1 \cdot \mathrm{d}^{-1}\right)$.

\section{Total specific deposit of organic solids}

The sand filter was divided into $n$ number of layers depending on the layer thickness $\Delta h$ and the height of filter $h$. In the $j$-th time step and for the $i$-th layer the concentration were calculated as follows:

$$
\begin{gathered}
C_{j, i}=C_{0} \cdot e^{-\lambda_{j, i} \cdot h_{i}} \\
\text { for } \quad i=1,2 . n \quad \text { and } h_{i}=i \cdot \Delta h
\end{gathered}
$$

where: $C_{0}$ - initial solids concentration VSS at $h=0\left(\mathrm{~g} \cdot \mathrm{dm}^{-3}\right)$.

In the equation (2) the ratio $d \sigma / d t$ of differential expression was replaced by retrograde (backward-difference formula): 


$$
\frac{d \sigma}{d t}=\frac{\sigma_{j}-\sigma_{j-1}}{\Delta t}
$$

Similarly, the gradient of concentration changes between adjacent layers ( $i-1$ and $i$ ) of the filter in the equation (2), was calculated as:

$$
-\frac{d C}{d h}=\frac{C_{i}-C_{i-1}}{\Delta h}
$$

After substituting (7) and (8) with taking account (6) to the equation (2) and the transformation of the relationship obtained for calculating the deposited solids of $\sigma$ in the $j$-th time step with $i$-thlayer - equation (9) can be proposed:

$$
\sigma_{j, i}=\sigma_{j-1, i}+q \cdot\left(\frac{C_{j, i-1}-C_{j, i}}{\Delta h}\right) \cdot \Delta t .
$$

Due to the specific deposit of solids $\sigma$ increase, the pore effective volume decreases and the probability of solids deposition becomes less and less. Due to this reason the changes in filter coefficient values are inverse to solids deposit changes.

The specific deposit increases in time as long as the maximum value is reached (Figure 1b). Then the deposition in particular filter layer finishes and deposition processes become more intensive in underlying layers.

Changes of filter coefficient $\lambda$ taking into account the deposited solids were calculated according to the equation in a form:

$$
\lambda_{j, i}=\lambda_{0} \cdot\left(\frac{\sigma_{\max }-\sigma_{j, i}}{\sigma_{\max }}\right),
$$

Calculations using the equations (9) and (10) were repeated for subsequent time steps
$t_{j+1}=t_{j}+\Delta t$ until their completion after reaching the set time.

In this study it was assumed that the changeability of solids capture probability with depth is related to solids deposition. This corresponds to the Min's [2013] hypothesis that particle capture probability decreases when filter depth increases. As a results of calculations of equations 9 and 10 the functions of $\lambda$ and $s$ were plotted (Figure 1).

The model proposed by authors of this article is based on the Iwasaki's equations (1) and (2) [Iwasaki 1937] and discussed by [Ives 1960; Ives 1969; Ives 1975] with taking into account the biomass concentration described by the logistic function $\left(\sigma_{b}\right)$.

Taking into account the biomass concentration the total specific deposit of organic solids $\sigma_{T O T}$ (expressed as VSS) can be calculated as follows:

$\sigma_{T O T j, i}=\sigma_{j-1, i}+q \cdot\left(\frac{C_{j, i-1}-C_{j, i}}{\Delta h}\right) \cdot \Delta t+\left(\sigma_{b_{j}}-\sigma_{b j-1}\right)$

where: $\sigma_{\text {TOT }}$ - total specific deposit of organic solids $\left(\mathrm{g} \cdot \mathrm{dm}^{-3}\right)$;

Changes of filter coefficient $\lambda$ taking into account the total specific deposit of organic solids $\left(\sigma_{T O T}\right)$ was calculated according to the equation in a form:

$$
\lambda_{j, i}=\lambda_{0} \cdot\left(\frac{\sigma_{\max }-\sigma_{T O T} j, i}{\sigma_{\max }}\right),
$$

where: $\lambda$ - filter coefficient taking into account the total specific deposit of organic solids $\left(1 \cdot \mathrm{m}^{-1}\right)$;
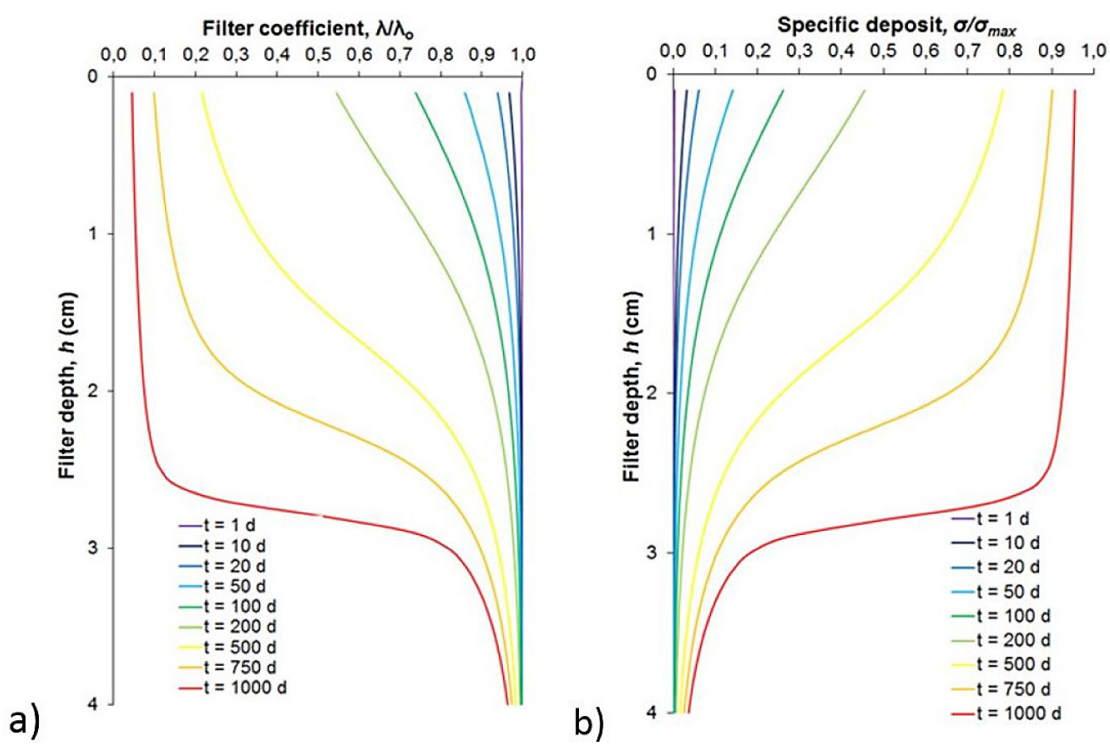

Figure 1. Variability in filter coefficient $l$ (a) and specific deposit of solids $\sigma(\mathrm{b})$ in time and filter depth 
The correspondence of the filter coefficient value with the capture probability would appear to be very precise but needs detailed information related to particle size distribution, which is sometimes difficult or impossible even in the case of septic tank effluent - there is no data related to this feature.

\section{MATERIAL AND METHOD}

\section{Identification of model parameters - initial value of filter coefficient}

Three transparent pipes were filled with a $1.0 \mathrm{~cm}$ layer of fine sand (according to Figure 2, pipes marked from A to C). After saturation of the soil (slow submergence into distilled water), the water surface was maintained at about $5 \mathrm{~cm}$ above the soil sample surface. The procedure allows to preserve the soil sample with undistributed structure.

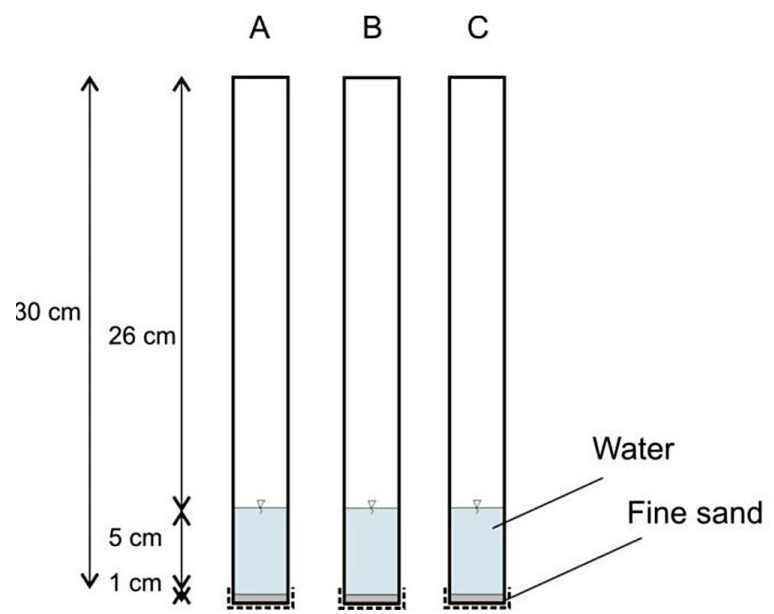

Figure 2. The sand filter test device for initial filter coefficient estimation

Then the wastewater was added (concentration of organic matter was equal $(0.42 \pm$ $\left.0.04) \cdot 10^{-3} \mathrm{~g} \cdot \mathrm{dm}^{-3}\right)$. Organic matter concentration difference between the inlet and outlet was used to estimate initial filter coefficient according to the equation:

$$
\lambda_{0}=\frac{1}{l} \ln \left(\frac{C_{\text {out }}}{C_{0}}\right)
$$

where: $C_{\text {out }}$ - outflow solids concentration (VSS $\left.\mathrm{g} \cdot \mathrm{dm}^{-3}\right)$

$l$ - thickness of filtration layer (m).
The calculation based on the measurements showed that the filter coefficient for the analyzed soil was equal to $117.2 \pm 15.11 \cdot \mathrm{m}^{-1}(n=3)$.

\section{Biomass concentration}

The aim of this experiment was to determine biomass concentration characteristics as a function of nutrients (identified as chemical oxygen demand, COD) concentration in septic tank effluent and time of STE application. This experiment was conducted using filtered and unfiltered STE on five filtering sand columns. The biomass concentration and viable bacteria cells (cells count - CFU) in the filters were determined.

The samples for biomass measurement were taken after 1, 2, and 3 weeks of wastewater application and samples for viable bacteria cells counting (as cell forming units - CFU) were taken after 5 weeks. For the purposes of accumulated biomass determination $30 \mathrm{~g}$ of sand samples were taken (3 samples for each filter) and for viable bacteria cells counting $-60 \mathrm{~g}$ of sand samples were taken, shaken in $250 \mathrm{~cm}^{3}$ of water and then, after stabilization, stained with crystalline violet.

No $\mathrm{BOD}_{5}$ influence (in the range of $26.0 \cdot 10^{-3}$ $\left.\mathrm{g} \cdot \mathrm{dm}^{-3}-143.0 \cdot 10^{-3} \mathrm{~g} \cdot \mathrm{dm}^{-3}\right)$ on variable bacteria concentration ( $\mathrm{CFU}$ ) in the sand filter was found. The viable bacteria cells number in sand in relation to the substrate concentration was as follows: $3.3 \pm 1.4 \cdot 10^{7} \mathrm{CFU} \cdot \mathrm{g}^{-1}$ for $0.026 \mathrm{~g}$ $\mathrm{BOD}_{5} \cdot \mathrm{dm}^{-3}, 4.0 \pm 3.2 \cdot 10^{7} \mathrm{CFU} \cdot \mathrm{g}^{-1}$ for $0.053 \mathrm{~g}$ $\mathrm{BOD}_{5} \cdot \mathrm{dm}^{-3}, 4.2 \pm 1.9 \cdot 10^{7} \mathrm{CFU} \cdot \mathrm{g}^{-1}$ for $0.106 \mathrm{~g}$ $\mathrm{BOD}_{5} \cdot \mathrm{dm}^{-3}, 3.8 \pm 0.9 \cdot 10^{7} \mathrm{CFU} \cdot \mathrm{g}^{-1}$ for $0.143 \mathrm{~g}$ $\mathrm{BOD}_{5} \cdot \mathrm{dm}^{-3}(n=3)$.

During the study no maximum specific deposit of solids was identified. So literature data were analyzed [Platzer and Mauch 1997] and the theoretical value: $266 \mathrm{~g} \cdot \mathrm{dm}^{-3}$ of maximum (measured as VSS) deposit of solids $\left(\sigma_{\max }\right)$ was proposed as $70 \%$ (30\% maximum water content was noted by Platzer and Mauch 1997) of the investigated sand porosity (38\%).

A logistic function (eq. 5) was assessed as the most appropriate for description of biomass concentration $\sigma_{b}$ in respect to empirical data. The basic term in this model $K$ is reaching by the population a stable maximum concentration (number) after particular time due to the limited environmental capacity. Several empirical data (Table 1) were used for logistic function plotting and fitting (Figure 3). 
Table 1. Data used for logistic function plotting and fitting

\begin{tabular}{|c|l|c|c|c|l|}
\hline No. & \multicolumn{1}{|c|}{ Data source } & $\begin{array}{c}\text { Biomass concentration } \\
\left(\mathrm{g} \cdot \mathrm{dm}^{-3}\right)\end{array}$ & $\begin{array}{c}\text { Time } \\
(\mathrm{d})\end{array}$ & $\begin{array}{c}\text { Filter depth } \\
(\mathrm{cm})\end{array}$ & \multicolumn{1}{|c|}{ Type of soil } \\
\hline 1 & Vinten et al. [1983] & 0.150 & 1 & 5 & sandy loam \\
\hline 2 & Spychała and Błażejewski [2003] & $4.550(\mathrm{av})$. & 500 & $7-30$ & fine sand \\
\hline 3 & Siegrist [1987] & 5.200 & 2130 & 5 & silty clay loam \\
\hline 4 & Siegrist [1987] & 3.900 & 2130 & 8 & silty clay loam \\
\hline
\end{tabular}

Spychała and Błażejewski [2003] did not observe the significant variability of biomass concentration in the filter up to the $30 \mathrm{~cm}$ of depth. The depth of $7.0 \mathrm{~cm}$ was chosen as the minimum distance from inlet filter surface, where no volatile suspended solids originating from wastewater was observed (in a fine sand the suspended solids are captured in a thin layer of filter - over $40 \%$ is accumulated down to $5 \mathrm{~cm}$ ). The following assumed fitting parameters were used: $K=4.550$ $\mathrm{g} \cdot \mathrm{dm}^{-3}, \sigma_{b 0}=0.250 \mathrm{~g} \cdot \mathrm{dm}^{-3}$ and $r=0.111 \cdot \mathrm{d}^{-1}$. The high fitting was achieved (regression coefficient

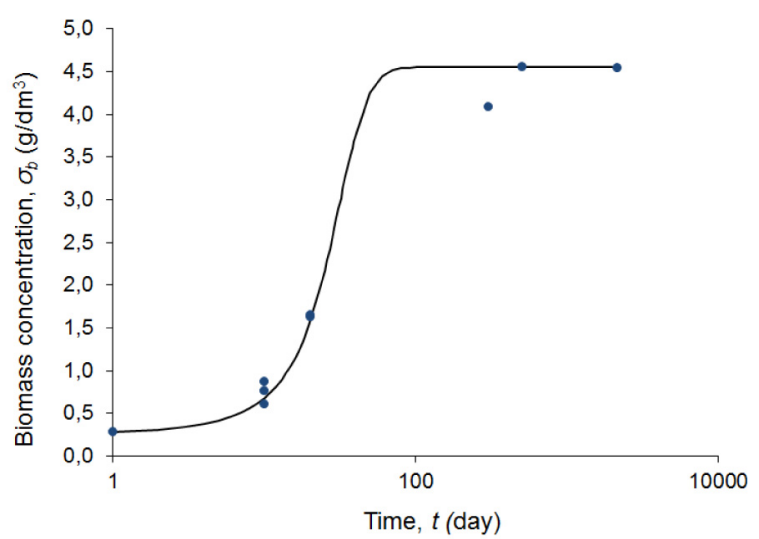

Figure 3. Fitting of logistic function to empirical data

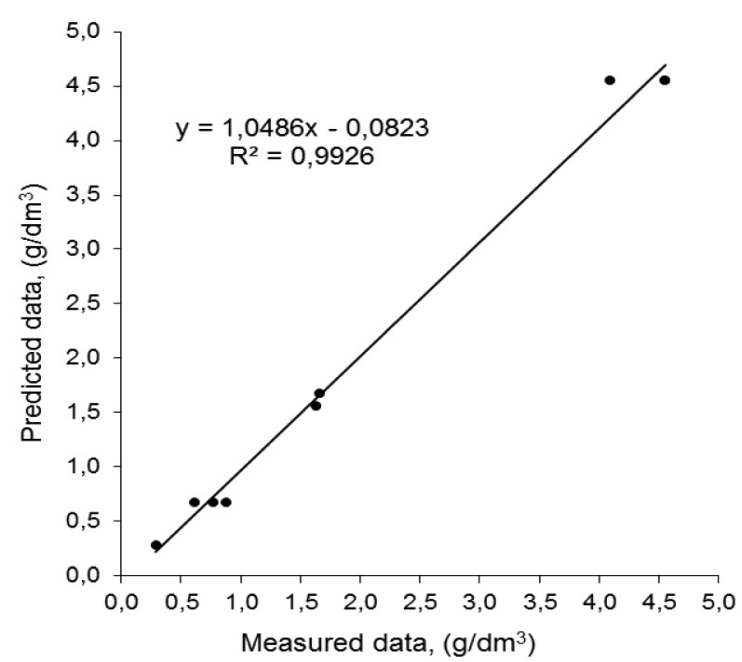

Figure 4. Relationship between predicted (fitting of logistic function) and measured biomass concentration $\sigma_{b}$
0.99). The result of logistic function plotting was shown in Figures 3 and 4.

Most of the experimental values were very close to the modelling values for a relatively long time - more than 300 days. It is worth to note that the most probable clogging time in practice is in similar range - several hundred days. For this time of operation empirical data values in deeper layers were in relatively narrow range: $3.090-4.550 \mathrm{~g} \cdot \mathrm{dm}^{-3}$ of dry sand.

\section{Experimental set-up}

The assessment of biomass accumulation and its impact on the Iwasaki model of sand filter clogging was carried out. The experiment was conducted by using laboratory filters on fine sand (effective grain size $d_{10}$ and $d_{60}$ were equal 0.1 $\mathrm{mm}$ and $0.3 \mathrm{~mm}$, respectively; uniformity coefficient equal to 3) previously burned at $550{ }^{\circ} \mathrm{C}$.

The wastewater samples were collected from a single chamber (septic tank) of $3.0 \mathrm{~m}^{3}$ volume (length: $1.85 \mathrm{~m}$, diameter: $1.34 \mathrm{~m}$ ) equipped with an outflow filter made of porous material. The wastewater originated from four people family (two adults and two children). Average wastewater outflow of four months was equal to $105 \mathrm{dm}^{3}$ per person per day. The concentrations of suspended solids and volatile suspended solids in septic tank effluent were (148.5 \pm $17.9) \cdot 10^{-3} \mathrm{~g} \cdot \mathrm{dm}^{-3}$ and $(93.0 \pm 11.6) \cdot 10^{-3} \mathrm{~g} \cdot \mathrm{dm}^{-3}$, respectively.

In order to accelerate the clogging process it was decided to use concentrated septic tank effluent. One of the best known procedures is evaporation by heating up to the temperature not damaging biological and organic material (e.g. amino acids) structures. The concentrated STE was prepared, using a vacuum evaporation set described earlier [Spychała et al. 2013]. The vacuum pump AT100B, which can generate a pressure down to $2 \mathrm{hPa}$ at $20^{\circ} \mathrm{C}$ was used.

The evaporation process reduces the temperature of wastewater and the heating is needed to maintain the temperature at approximately $20^{\circ} \mathrm{C}$. 
The concentrated STE (septic tank effluent) was dosed with a COD of $1.606 \pm 0.282 \mathrm{gO}_{2} \cdot \mathrm{dm}^{-3}$; $\mathrm{SS}=0.592 \pm 0.228 \mathrm{~g} \cdot \mathrm{dm}^{-3}$ and VSS $=0.380 \pm$ $0.003 \mathrm{~g} \cdot \mathrm{dm}^{-3}$. The solids range is comparable to reported by other authors: $0.280-0.375 \mathrm{~g} \cdot \mathrm{dm}^{-3}$ of volatile suspended solids [Tehrani 2009]. After the predetermined time was achieved, the columns were disassembled. The specific deposit of solids (identified as VSS) was measured at every level of sand filter (each one cm layer of sand filter was burned).

The main experiment was carried out using laboratory filters. Six transparent pipes of the height of $30 \mathrm{~cm}$ and the diameter of $2.6 \mathrm{~cm}$ were used (Figure 5 pipes: D - I). All the filters were filled with a $14 \mathrm{~cm}$ layer of fine sand with the same characteristic as used to estimate initial filter coefficient. The research on the three columns was carried out for ten days and the other two columns (pipe number I has broken-down during the study) were continued for twenty days.

\section{Input data used for modelling}

Verification of the model was based on empirical research. The modelling data were plotted for the specific deposit of solids (expressed as volatile suspended solids) concentration in waste-

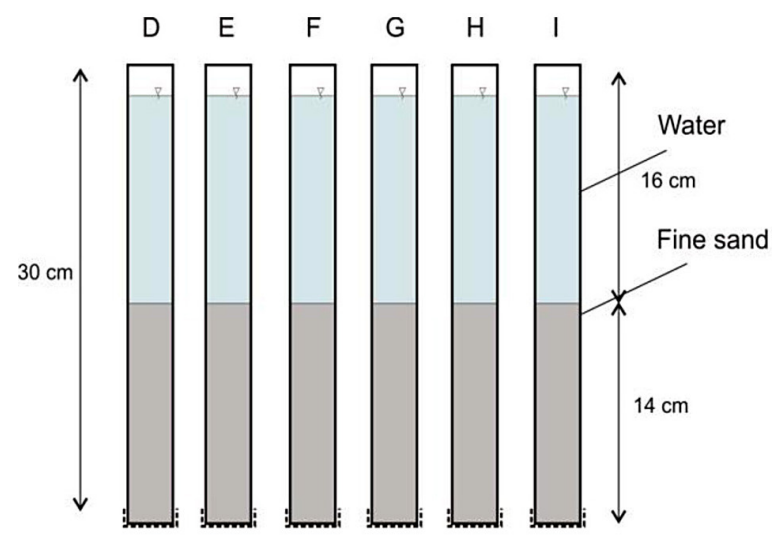

Figure 5. Experimental set up

Table 2. Input data used for modelling

\begin{tabular}{|l|c|c|}
\hline \multicolumn{1}{|c|}{ Parameter } & Symbol & Value \\
\hline Hydraulic load $\left({\left.\mathrm{m} \cdot \mathrm{d}^{-1}\right)}^{-1}\right)$ & $q$ & 0.02 \\
\hline $\begin{array}{l}\text { Initial solids concentration (VSS, } \\
\left.\mathrm{g} \cdot \mathrm{dm}^{-3}\right)\end{array}$ & $C_{0}$ & 0.3804 \\
\hline Initial filter coefficient $\left(1 \cdot \mathrm{m}^{-1}\right)$ & $\lambda_{0}$ & 117 \\
\hline Simulation time step $(\mathrm{d})$ & $\Delta t$ & 1 \\
\hline Soil layer depth for calculation $(\mathrm{m})$ & $\Delta h$ & 0.001 \\
\hline $\begin{array}{l}\text { Maximum specific deposit of solids } \\
\left(\text { VSS } \mathrm{g} \cdot \mathrm{dm}^{-3}\right)\end{array}$ & $\sigma_{\max }$ & 266 \\
\hline
\end{tabular}

water $C_{0}: 0.3804 \mathrm{~g} \cdot \mathrm{dm}^{-3}$ and this same value was used during empirical research.

The experiment allowed the determination of the following parameters used in modeling. Data involved in modelling was presented in Table 2.

\section{RESULTS}

The result of the research showed that the total specific deposit of organic solids (expressed as volatile suspended solids-originated from STE and biomass) depends on the filter depth.

The use of Iwasaki model without taking into account the biomass concentration $(\sigma)$ causes at a depth greater than $3 \mathrm{~cm}$ that concentration drops to zero (Figure 6a). Experimental results indicate that the biomass growth is noticeable over the entire depth of the filter.

The biomass concentration should be added as a result of dissolved substrate (organic carbon measured as $\mathrm{COD}$ or $\mathrm{BOD}_{5}$ ) utilization by live microorganisms (bacteria mainly). The approximated value can be taken from other investigations made under comparable conditions. In the Spychała and Błażejewski [2003] study a live biomass concentration was noted of about 5.0 $\mathrm{g} \cdot \mathrm{dm}^{-3}$ of dry sand. A comparable value can be calculated using the graph given by Leverenz et al. [2009] $-9.0 \mathrm{~g} \cdot \mathrm{dm}^{-3}$ of dry sand $\left(12.0 \mathrm{mg} \cdot \mathrm{g}^{-1}\right.$ of dry sand at $3.6 \mathrm{~g} \mathrm{TSS} \mathrm{m}^{-2} \cdot \mathrm{d}^{-1}$ - the same value as in Spychała and Błażejewski [2003] study).

The empirical data distributions (for 10 and 20 days of operation) were close to the model lines. The results are presented in Figure 6. Both in the case of empirically determined (measured) and modelled biomass concentration distribution, the highest values were obtained (model) and observed (semi-technical scale experiment) in the thin, top filter layer: $0-3 \mathrm{~cm}$ of depth (Figure 6).

Similar empirical results were obtained by other authors, e.g. Renman et al. [2008] - for carbon and nitrogen distribution in the sand column during on-site wastewater application. A comparable distribution of biomass concentration as a result of modelling bacteria growth in the sand column supplied with substrate was obtained by Brovelli et al. [2009]. It is worth noting that immobile biomass content with bio-clogging was observed mainly in (for Courant number, $\mathrm{Cr}$, equal 0.1 ) the top $0-10 \mathrm{~cm}$ layer of filter, and in the column without bio-clogging - in the thinner top layer: $0-7.0 \mathrm{~cm}$ ). The most similar values of 
a)

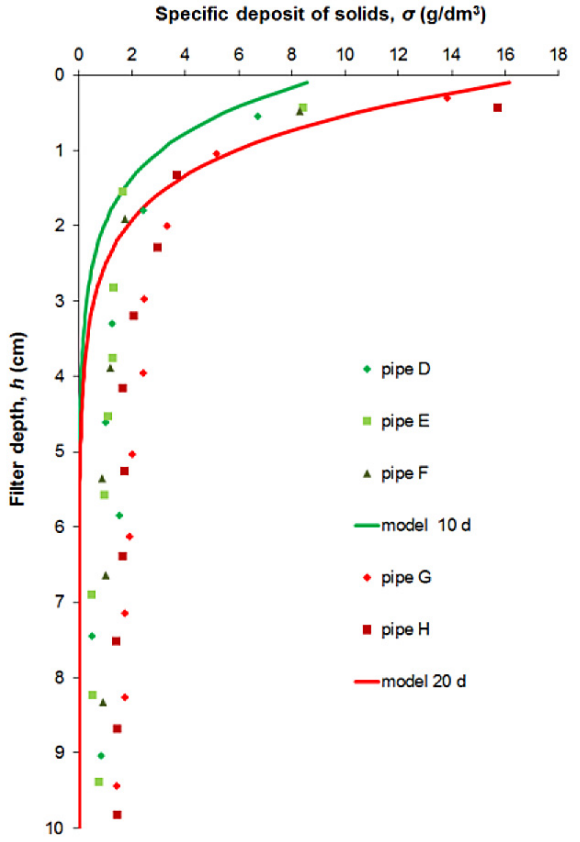

b)

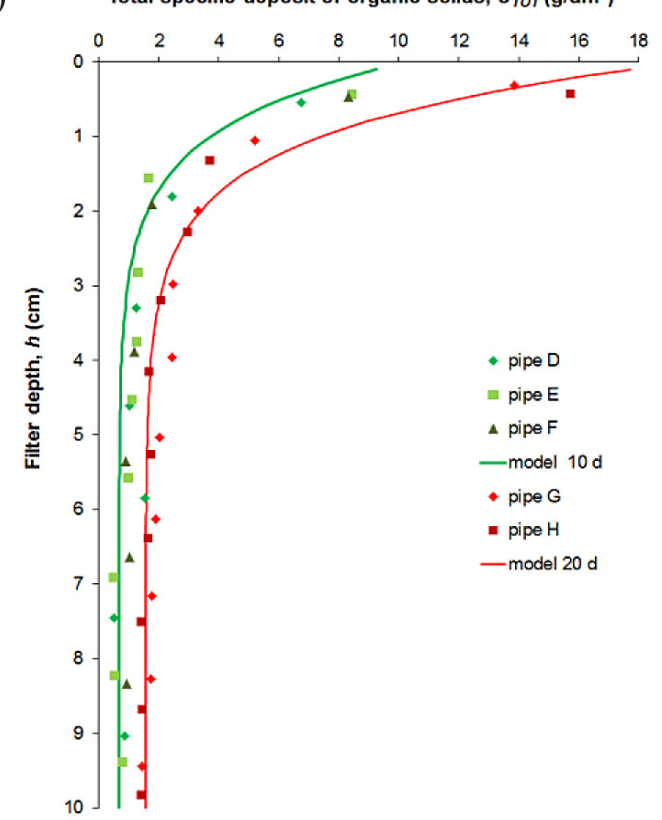

Figure 6. Empirical data distributions and model results for 10 and 20 days of operation: deposit of solids (left) and total specific deposit of organic solids (taking into account the biomass concentration $s_{O T}$ ) (right)

vertical distribution in the sand column to this study were obtained by Brovelli et al. [2009] for substrate concentration - showing a drastic decrease of concentration below $3-4 \mathrm{~cm}$ filter depth.

It is an interesting fact that despite different conditions and processes in unsaturated soils, there are examples of modelled distribution of matter (e.g. microbial) similar to saturated soils in the filter vertical profile. Mostafa and Van Geel [2007] presented modelled microbial saturation dominated (over 95\%) in the top $1.5 \mathrm{~cm}$ of the peat column and a similar rate of content in the top $4-5 \mathrm{~cm}$ of the sand soil filter.

The dry organic mass distribution in the sand column vertical profile obtained as modelling and experimental results during this study correspond to other authors' reports, especially for small grain diameter soils such as fine sand [Zhao et al. 2009].

There are many examples of grain diameter and clogging layer thickness association in the literature. Burčak [1978] for example, reported a very low clogging layer thickness (about $2.0 \mathrm{~cm}$ ) for intermittent filters with a $0.13 \mathrm{~mm}$ effective grain diameter. Kawanishi et al. in turn [1989] observed a very thin $-3.0 \mathrm{~mm}$ clogging layer in andosols. Similarly, a very shallow clogging layer was detected by Thomas et al. [1966], showing a $0-1.0 \mathrm{~cm}$ of filter depth. A similar but somewhat higher clogging layer thickness was observed by Siegrist [1987], which demonstrated several top centimeters in this regard and by Laak [1986], who observed this at a depth of $0.5-3.0 \mathrm{~cm}$, while Miller et al. [1994] reported 30\% of total solids mass accumulated in the top filter layer (0-2.5 $\mathrm{cm})$. The highest organic mass concentration in the top $(0.0-3.0 \mathrm{~cm})$ layer of vertical filter of $0.25-0.5 \mathrm{~mm}$ grain diameter was observed by De Vries [1972].

Some authors, therefore, suggested a significant role of large particles of suspended solids inflowing with liquid to the filter [Vinten 1983], highlighting the high ratio of large particles to the whole mass accumulated in the clogging layer (about half). However, others in the literature do not confirm this association, reporting a lack of correlation between total suspended solids diameter and clogging process velocity [Laak 1970].

The good convergence was achieved (regression coefficient 0.976 for 10 days of operation and 0.952 for 20 days of operation). The results were presented in Figure 7 and Figure 8.

\section{CONCLUSIONS}

In this paper the authors have proposed a new approach to model, which describes dry organic mass from septic tank effluent and biomass distribution in a sand filter. In this approach the variable filter coefficient value was used as affected by depth and time of operation and the biomass concentration was approximated by a logistic function. 


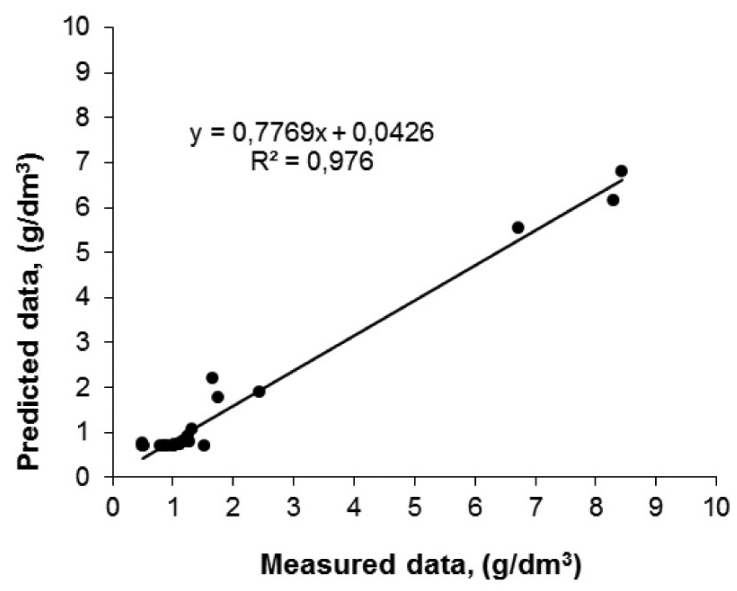

Figure 7. Relationship between predicted and measured total specific deposit of organic solids $\left(s_{T O T}\right)$ after 10 days

The following conclusions can be drawn from this study:

1. The Iwasaki model can be satisfactorily applicated as describing specific deposit of solids in sand filter receiving septic tank effluent but the extension the formula with the biomass concentration (resulting from dissolved nutrients utilisation) is reasonable;

2. The new approach to the filter coefficient interpretation - is possible as related to accumulated biomass concentration, time and depth;

3 . The novel approach was used to logistic function as a description of biomass concentration in deep bed filtration assessment - a relatively stable biomass (measured as volatile solids) contents were observed in several empirical studies [Spychała 2003; Siegrist 1987; present study] after several hundred days of maintenance (300 - 2130 days) - about 3.9 - $5.2 \mathrm{mg}$ per $1 \mathrm{~cm}^{3}$ of small grain diameter filtering material (fine sand and silty clay loam);

4. The Iwasaki equations associated with logistic function are useful for the prediction of mechanical and biological clogging in sand filters;

5. Future studies related to live biomass concentration in porous media during sewage filtration are needed, beside the growth and decay rate one very important factor is maximum biomass concentration;

6. The further studies are needed for accumulated matter volume identification. In this calculation the relatively high density (low water content) of organic matter accumulated

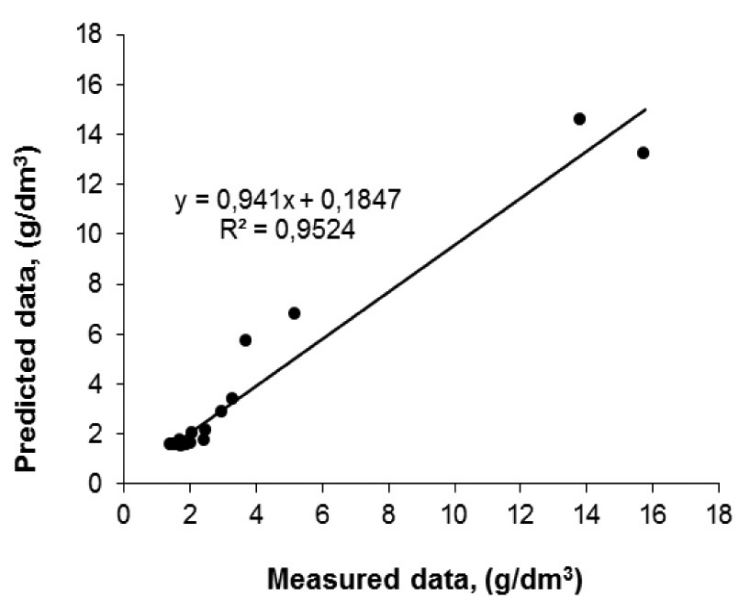

Figure 8. Relationship between predicted and measured total specific deposit of organic solids $\left(s_{T O T}\right)$ after 20 days

in the filter study was based on the literature data; however, there are several procedures to convert the measured distributions by mass or volume [Rhodes 2008].

\section{Acknowledgements}

This work was supported by the Polish National Science Centre under Grant (No. N305316740).

\section{REFERENCES}

1. Aggrey S.E. 2002. Comparison of three nonlinear and spline regression models for describing chicken growth curves., Poultry Science 81, 1782-1788.

2. Bai R., Tien C.A. 1996. New correlation for the initial filter coefficient under unfavorable surface interactions. J. Colloid. Interf. Sci. 179, 631-634.

3. Bedrikovetsky P., Siqueira F.D., Furtado C.A., Souza A.L-S. 2011. Modified particle detachment model for colloidal transport in porous media. Transport in Porous Med. 86, 353-383.

4. Begon M., Mortimer M. 1981. Population ecology: A unified study of animals and plants. Oxford: Blackwell Scientific Publications.

5. Błażejewski R., Murat-Błażejewska S. 1997 Soil clogging phenomena in constructed wetlands with subsurface flow. Water Sci Technol. 35(5), 183-188.

6. Bouma J. 1975. Unsaturated flow during soil treatment of STE. J. Environ. Eng. Proc. ASCE 101, 967-983.

7. Bradford S.A., Simunek J., Bettahar M., Van Genuchten M.T., Yates S.R. 2003. Modeling colloid attachment, straining, and exclusion in saturated porous media. Journal of Environmental Science 
and Technology 37, 2242-2250.

8. Brovelli A., Malaguerra F., Barry D.A. 2009 Bioclogging in porous media: Model development and sensitivity to initial conditions. Environmental Modelling \& Software 24, 611-626.

9. Burchak T.V. 1978 Infiltracionnye bassejnyIzdatelstvo Budivelnik. Kiev (in Ukrainian).

10. Campos L.C. 2002. Modelling and simulation of the biological and physical processes of slow sand filtration. Ph D thesis, Imperial College of Science, Technology and Medicine, London.

11. Cowan P.A., Middlebrooks E.J. 1980. A model and design equations for the intermittent sand filtration. Environmental International, 4, 339-350.

12. De Vries J. 1972 Soil filtration of wastewater effluent and the mechanism of pore clogging. Journal WPCF, 44 (4), 565-573.

13. Duncan C.S., Reneau J., Hagedorn C. 1994. Impact of effluent quality and soil depth on renovation of domestic wastewater. Proceedings of the $7^{\text {th }}$ National Symposium on Individual and Small Community Sewage Systems, ASAE, St. Joseph, Mich., 219-228.

14. Elimelech M., O’Melia C.R. 1990. Effect of particle size on collision efficiency in the deposition of Brownian particles with electrostatic barriers. Langmuir 6 (6), 1153-1163.

15. Fallah H., Fathi H.B., Mohammadi H. 2012. The mathematical model for particle suspension flow through porous medium. Geomaterials 2, 57-62.

16. Farajzadeh R. 2004. Produced water re-injection (PWRI): an experimental investigation into internal filtration and external cake build up. PhD, Delft University of Technology, The Netherlands.

17. Foppen J.W.A., Schijven J.F. 2006. Evaluation of data from the literature on the transport and survival of Escherichia Coli in aquifers under saturated conditions. Water Res. 40(3): 401-426.

18. Fresco L.F.M. 1973 A model for plant growth. Estimation of the parameters of the logistic function. Acta Botanica Neerlandica 22(5), 486-489.

19. Herzig J.P., Leclerc D.M., Le Goff P. 1970. Flow of suspension through porous media-application to deep filtration. J. Ind. Eng. Chem. 65(5), 8-35.

20. Ives K.J. 1960. Rational design of filters. Proc. of the Inst. of Civil Engineers16(2), 189-193.

21. Ives K.J. 1969. Theory of filtration. Special Subject No. 7, IWSA Congress, Vienna, 1591.

22. Ives K.J. 1975. Capture Mechanisms in Filtration. NATO Advanced Study Institute, Series E, Applied Sciences, No. 2, Noordhoff International, Leyden.

23. Iwasaki T., Slade Jr. J.J., Stanley Wm. E. 1937. Some notes on sand filtration. J. Am. Water Works Ass. 29(10), 1591-1602.
24. Jabur H. 1976. Slow Sand filters and its role in water treatment. Ph D Thesis, Hungarian Academy of Sciences, Hungarian.

25. Jabur H.S., Mårtensson J., Öllös G. 2005. Some notes on hydraulics and a mathematical description of slow sand filtration. Vatten 61, 193-200.

26. Jegatheesan V., Vigneswaran S. 1997. The effect of concentration on the early stages of deep bed filtration of submicron particles. Water Res. 31(11), 2910-2913.

27. Jegatheesan V. 1999. Effect of surface chemistry in the transient stages of deep bed filtration. Ph D Thesis, University of Technology, Sydney.

28. Kawanishi T., Kawashima H., Chihara K., Suzuki M. 1989. Effect of biological clogging on infiltration rate in the soil treatment systems. Proceedings of the International Specialized Conference on Design and Operation of Small Wastewater Treatment Plants, Trondheim, Norway pp. 105-112.

29. Keir G., Jegatheesan V., Vigneswaran S. 2009. Deep bed filtration: Modelling theory and practice. Waste pp 1-6, Oxford: EOLSS Publishers.

30. Knowles P., Dotrob G., Nivala J., García J. 2011. Clogging in subsurface-flow treatment wetlands: Occurrence and contributing factors. Ecol. Eng. 37, 99-112.

31. Laak R. 1970 Influence of domestic wastewater pretreatment on soil clogging. Journal Water Pollution Control Fed. 1495-1500.

32. Laak R. 1986 Wastewater Engineering Design for Unsewered Areas. Technomic Publishing Co., Inc, Basel-Lancaster.

33. Langenbach K., Kuschk P., Horn H., Kästner M. 2010. Modeling of slow sand filtration for disinfection of secondary clarifier effluent. Water Res. 44, 159-166.

34. Leverenz H.L., Tchobanoglous G., Darby J.-L. 2009. Clogging in intermittently dosed sand filters used for wastewater treatment, Water Res. 43, 695-705.

35. Logan B.E., Jewett D.G., Arnold R.G., Bouwer E.J., O’Melia C.-R. 1995. Clarification of clean-bed filtration models. J. Environ. Eng. $121,869-873$.

36. Logan D.J. 2001. Transport modeling in hydrogeochemical systems. Publisher: Springer, New York, USA, 30-34.

37. Miller D.A., Sack W.A., Dix S.P.; Misaghi F.K., Lambert M.E. 1994. Solid accumulation in recirculating sand filters. Proceedings of the $7^{\text {th }}$ National Symposium on Individual and Small Community Sewage Systems, Atlanta, ASAE.

38. Min X., Shu L., Li W., Appiah-Adjei E. -K. 2013. Influence of particle distribution on filter coefficient in the initial stage of filtration. Korean J. 
Chem. Eng. 30(2), 456-464.

39. Mostafa M., Van Geel P.J. 2007. Conceptual models and simulations for biological clogging in unsaturated soils.

40. Nieć J., Spychała M., 2014. Hydraulic conductivity estimation test impact on long-term acceptance rate and soil absorption system design. Water 6(9), 2808-2820.

41. Öllös G., Vizellatas 1987. Aqua, Kiado, Budapest.

42. Pell M., Ljunggren H. 1996. Composition of the bacterial population in sand-filter columns receiving artificial wastewater, evaluated by soft independent modelling of class analogy (SIMCA). Water Res. 30(10), 2479-2487.

43. Platzer C., Mauch K. 1997. Soil clogging in vertical flow reed beds - mechanisms, parameters, consequences and solutions? Water Sci. Technol. 35(5), 175-181.

44. Puigagut J., Caselles-Osorio A., Vaello N., García J. 2008. Fractionation, biodegradability, and particle-size distribution of organic matter in horizontal subsurface-flow constructed wetlands. Dordrecht, Springer, 21.

45. Renman A., Hylander L.D., Renman G. 2008 Transformation and removal of nitrogen in reactive bed filter materials designed for on-site wastewater treatment. Ecological Engineering 34, 207-214.

46. Rhodes M. 2008. Introduction to Particle Technology. 2nd Edition. Chichester: John Wiley \& Sons Ltd.

47. Santos A; Bedrikovetsky P.; Fontoura S. 2008 Analytical micro model for size exclusion: Pore blocking and permeability reduction. J. Membrane Sci. 308(1-2), 115-127.

48. Shehabi A., Stokes J.R., Horvath A. 2012. Energy and air emission implications of a decentralized wastewater system. Environ. Res. Letters 7(2), 1-6.

49. Siegrist R.L. 1987. Soil clogging during subsurface wastewater infiltration as affected by effluent composition and loading rate. J. Environ. Qual. 16(2), 181-187.

50. Spychała M. 2003. Contaminants removal efficiency of sand filters treating septic tank effluent. Rocznik Akademii Rolniczej w Poznaniu 24, 191198 (in Polish).
51. Spychała M., Błażejewski R. 2003. Sand filter clogging by septic tank effluent. Water Sci. Technol. 48(11), 153-159.

52. Spychała M., Nieć J., Pawlak M. 2013. Preliminary study on filamentous particle distribution in septic tank effluent and their impact on filter cake development. Environ. Technol. 34(20), 2829-2837.

53. Tehrani P.S. 2009. Efficiency of sand filter beds for the removal of bacteria from residential wastewater. MSc Thesis, The University of Guelph.

54. Thomas R.E., Schwartz W.A., Bendixen T.W. 1966. Soil chemical changes and infiltration rate reduction under sewage spreading. Soil Sci. Soc. Amer. Proc. 30, 641-646.

55. Tsoularis A., Wallace J. 2002. Analysis of logistic growth models. Mathematical Biosciences 179, $21-55$.

56. Tufenkji N. 2007. Colloid and microbe migration in granular experiments: A discussion of modelling methods. In: Frimmel F.H., Von der Kammer F., Flemming H.-C. (Eds.) Colloidal Transport in Porous Media, 1st ed., Springer-Verlag: Berlin, Germany, pp. 119-142.

57. Zamani A., Maini B. 2009. Flow of dispersed particles through porous media - Deep bed filtration. J. Petrol. Sci. Eng. 69, 1-2.

58. Zhao L., Wei Z., Wei T. 2009. Clogging processes caused by biofilm growth and organic particle accumulation in lab-scale vertical flow constructed wetlands. J. Environ. Sci. 21, 750-757.

59. Zwietering M.H., Jongenburger I., Rombouts F. M., Van't Riet, K. 1990. Modelling of the bacterial growth curve. Appl. Environ. Microb. 56(6), 1875-1881.

60. Valentukeviciene M. 2009. Applying backwash water in order to enhance removal of iron and ammonia from spent filters with fresh filter media. Environ. Prot. Eng. 35(3), 135-144.

61. Valentukeviciene M., Ignatavicius G. 2014. Improvement of phosphorus removal in the wastewater treatment. Ekologija. 60 (4), 65-72.

62. Vinten A.J.A., Mingelgrin U., Yaron B. 1983. The effect of suspended solids in wastewater on soil hydraulic conductivity: II. Vertical distribution of suspended solids. Soil. Sci. Soc. Am. J. 47(3), 408-412. 